\title{
Association between Mean Platelet Volume and Bone Mineral Density in Rheumatoid Arthritis
}

\author{
Romatoid Artritte Ortalama Trombosit Hacmi ile Kemik Mineral Yoğunluğu Arasındaki \\ Illișki
}

Betül Sargın

Aydın Adnan Menderes University Faculty of Medicine, Department of Physical Medicine and Rehabilitation, Division of Rheumatology, Aydın, Turkey

\begin{abstract}
Introduction: This study aimed to evaluate the mean platelet volume (MPV) levels in rheumatoid arthritis (RA) and determine whether there is a relationship between MPV and bone mineral density (BMD) measurement.

Methods: A total of 108 RA patients [31 osteopenia, 45 osteoporosis (OP), and 32 normal BMD] were included in the study. The age, gender, body weight, height, body mass index, MPV, calcium and vitamin D levels, and BMD scores were recorded.

Results: The mean age was $50.20 \pm 5.5$ years. The mean levels of MPV were $10.70,11.00$, and $10.55 \mathrm{fL}$ in the osteopenic, osteoporotic, and normal groups, respectively. The median weight and femoral neck T-score of the osteoporotic group were different from other groups. The median lumbar 1-4 T-score of all groups was different from each other. We found a negative correlation between MPV and femoral neck T-score.

Conclusion: Our study is the first to assess MPV levels in normal, osteopenic, and osteoporotic RA patients. However, we did not find similar results when the mean platelet levels of all three groups were compared. The correlation analysis showed that MPV elevation may be related to OP in the differential diagnosis for patients with RA.
\end{abstract}

Keywords: Bone mineral density, mean platelet volume, rheumatoid arthritis

\section{öZ}

Amaç: Bu çalıșmada romatoid artritte (RA) ortalama trombosit hacmi (MPV) düzeylerini değerlendirmeyi ve MPV ile kemik mineral yoğunluğu (KMY) ölçümü arasında bir ilişki olup olmadığını belirlemeyi amaçladık.

Yöntemler: Çalıșmamıza 108 RA hastası [31 osteopenik, 45 osteoporoz (OP), 32 normal KMY'ye sahip] dahil edildi. Hastaların yaş, cinsiyet, vücut ağırlığı, boy ölçüleri, vücut kitle indeksi, ortalama trombosit hacmi, kalsiyum ve D vitamini düzeyleri ve KMY skorları kaydedildi.

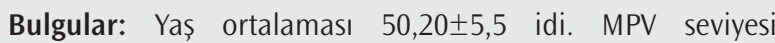
osteopenik grupta $10,70 \mathrm{fL}$, osteoporotik grupta $11,00 \mathrm{fL}$ ve normal grupta $10,55 \mathrm{fL}$ idi. Osteoporotik grubun ortanca ağırlık ve femur boynu T-skoru diğer gruplardan farklıydı. Tüm grupların medyan lomber 1-4 T-skoru birbirinden farklıydı. MPV ile femur boynu T-skoru arasında negatif korelasyon bulduk.

Sonuç: Çalıșmamız, normal, osteopenik ve osteoporotik RA hastalarında ortalama trombosit hacim düzeylerini değerlendiren ilk çalışmadır. Üç grupta ortalama trombosit düzeylerini karşılaștırdığımızda benzer sonuçlar bulamamış olsak da korelasyon analizi MPV yükselmesinin omatoid artritli hastalarda osteoporoz ile ilișkili olabileceğini göstermiştir.

Anahtar Kelimeler: Kemik mineral yoğunluğu, ortalama trombosit hacmi, romatoid artrit

\section{Introduction}

Rheumatoid arthritis (RA) is a chronic, symmetrical, and inflammatory autoimmune disease that affects the small joints, eyes, heart, kidneys, and lungs. The onset of this disease is usually from the age of 35 to 60 years (1). Management of RA includes conventional synthetic [diseasemodifying antirheumatic drugs (DMARDs); methotrexate, leflunomide, and sulfasalazine], targeted DMARDs (tofacitinib and baricitinib), and biological DMARDs (biosimilar and biological originator) (2). Early onset, joint counts at diagnosis, rheumatoid factor/anti-citrullinated protein antibody positivity, radiographic erosion, extra-articular manifestations, comorbidities, and low bone mineral density (BMD) are reported as poor prognostic factors for RA. Osteoporosis (OP) has been reported twice as common in patients with RA than the controls (3). Also, low peak bone mass, hormonal factors, glucocorticoids, smoking, low physical activity,
Address for Correspondence/Yazıșma Adresi: Betül Sargın MD, Aydın Adnan Menderes University Faculty of Medicine, Department of Physical Medicine and Rehabilitation, Division of Rheumatology, Aydın, Turkey

Phone: +90 5545929430 E-mail: betul.cakir@yahoo.com ORCID ID: orcid.org/0000-0002-9463-8413

Cite this article as/Atıf: Sargın B. Association between Mean Platelet Volume and Bone Mineral Density in Rheumatoid Arthritis. İstanbul Med J 2021; 22(2): 105-8.
Received/Geliș Tarihi: 13.06.2020 Accepted/Kabul Tarihi: 10.02.2021

(C) Copyright 2021 by the University of Health Sciences Turkey, Istanbul Training and Research Hospital/Istanbul Medical Journal published by Galenos Publishing House.

(C) Telif Hakkı 2021 Sağıı Bilimleri Üniversitesi Istanbul Ĕgitim ve Araştırma Hastanesi/Istanbul Tıp Dergisi, Galenos Yayınevi tarafından basılmıștır. 
low calcium/vitamin D intake, small body size, and family history of fracture are risk factors associated with OP (4).

OP is a global health problem with an expected increase in fracture prevalence and public health burden with morbidity and mortality in the elderly population (5). It is defined as a BMD with 2.5 standard deviations (SD) or more and T-score below the average value for young healthy women (6). It occurs with the imbalance between bone resorption and bone formation. Local or systemic bone loss can occur in RA. Systemic bone loss in RA has a multifactorial etiology. It is related to the patients' disability, therapy, and risk factors such as advanced age, sex, postmenopausal period, genetic predisposition, low peak bone mass, low body weight, calcium and vitamin D deficiency, and smoking. Local (periarticular) bone loss is related to the release of cytokines such as tumor necrosis factor-alpha (TNF- $\alpha$ ), interleukin (IL)-1, IL-6, receptor activator of nuclear factor- $\mathrm{KB}(\mathrm{NF}-\kappa \mathrm{B})$, and macrophage-colony stimulating factor. The receptor activator of NF- $\mathrm{B}$ ligand binds to the RANK receptor on osteoclast precursors and provokes osteoclast cell maturation (7). Pro-inflammatory cytokines such as IL-6 directly induce RANKL production through the Janus kinase/STAT pathway, STAT3 phosphorylation, and extracellular signal-regulated kinases (8).

Mean platelet volume (MPV) indicates the mean size of platelets and is widely used for platelet functions (9). There are numerous studies investigating the association between MPV and BMD (10-13). In a study, a negative correlation was found between MPV and femoral neck-lumbar spine BMD (11). Lower MPV and platelet distribution width (PDW) levels were found in OP than in the normal BMD group. Moreover, PDW was positively correlated with femur total and lumbar T-scores (12). In another study, a significantly positive correlation was found between MPV and femoral neck BMD in the normal weight osteoporotic group (13).

Megakaryocytes are responsible for platelet production and have increased osteoblast proliferation in vivo and in vitro (14). The role of platelets in bone remodeling has been investigated in Kim et al.'s (15) study. They analyzed the data of 5181 postmenopausal women and over 50 years of age men in the Korea National Health and Nutrition Examination Survey and data of 3,312 adults over 50 years of age in the Korean Genome and Epidemiology Study. The study found that the highest platelet counts were associated with osteopenia and OP in middle-aged and elderly individuals (15). D'Amelio et al. (16) reported that platelets have decreased vitamin D receptors in OP. The relationship between MPV and OP may be due to megakaryocytes' role in osteoblast proliferation (15) and decreased vitamin $\mathrm{D}$ receptors of platelets in OP (16). However, the exact mechanism of the relationship between MPV and BMD in RA patients is not yet known. It has been investigated in postmenopausal women (16).

Therefore, we aimed to evaluate MPV levels in RA patients and determine whether there is a relationship between MPV and BMD measurement.

\section{Methods}

A total of 108 patients with RA who were admitted to Adnan Menderes University Faculty of Medicine, Department of Physical Medicine and Rehabilitation, Division of Rheumatology were enrolled in the study. All RA patients were diagnosed according to the American
College of Rheumatology/European League Against Rheumatism 2010 criteria (17). The patients were treated with bisphosphonates (alendronate, ibandronic acid, and zoledronic acid) for OP and DMARDs (methotrexate, hydroxychloroquine, sulfasalazine, and leflunomide) for RA. Patients who were in the postmenopausal age, were pregnant and breastfeeding, have a spinal implant history, used drugs that cause OP, and have malignancies such as leukemia, lymphomas, and immune thrombocytopenic purpura were excluded from the study. Our study was conducted according to the criteria set by the Declaration of Helsinki, and the Aydın Adnan Menderes Faculty of Medicine Ethics Committee approved the study (approval no: 2017/1123, date: 23.03.2017). Written informed consent was obtained from all patients.

The age, gender, body weight, height, body mass index (BMI), MPV, calcium and vitamin D levels, and BMD scores were recorded for this retrospective study. BMI was calculated using the formula of weight/ height $^{2}$, where height is expressed in meters and weight in kilograms. Dual-energy X-ray absorptiometry (Hologic, Inc., Waltham, MA, USA) was used to assess BMD in two bone sites of the femur (neck, intertrochanteric zone, and trochanter) and spinal lumbar vertebrae (Lumbar 1-4). OP was determined based on the World Health Organization criteria as follows: BMD T-score of -1.0 or more is normal, -2.5 and -1.0 is low bone mass (osteopenia), and -2.5 or less is OP. Compression fractures were evaluated using medical history, physical examination, and, if necessary, radiography in patients.

\section{Statistical Analysis}

The data were analyzed using the SPSS version 19.0. Descriptive statistics were presented as number, frequency $(\%)$, mean \pm SD, and median $\left(25^{\text {th }}\right.$. $75^{\text {th }}$ percentile). The Kolmogorov-Smirnov test examined whether the variables were normally distributed or not. Mann-Whitney $U$ test was used to compare not normally distributed differences between groups. Spearman's correlation test was used to determine the relationship between quantitative nonnormally distributed variables. A correlation coefficient $r$ value of $0.00-0.19$ is defined as "very weak," $0.20-0.39$ as "weak," 0.40-0.59 as "moderate," 0.60-0.79 as "strong," and 0.81.0 as "very strong." The results were assessed at 95\% confidence interval, and a p-value of less than 0.05 was considered significant.

\section{Results}

A total of 108 patients with RA were included in the study. The mean age of RA patients was $50.2 \pm 5.5$ years. Of patients, $12 \%$ were men and $88 \%$ women. Patients were divided into three groups according to BMD results as follows: Normal, osteopenic, and osteoporotic patients. The demographic and laboratory features of the patients are shown in Table 1. No significant differences were found between the groups in terms of age, MPV, and calcium and vitamin D levels (Table 1). The median height and BMI of the osteoporotic and normal groups were different from each other $(p<0.001$ and $p=0.024$, respectively). The median weight and femoral neck $\mathrm{T}$-score of the osteoporotic group were different from other groups $(p<0.001$ and $p<0.001$, respectively). The median lumbar 1-4 T-score of all groups was different from each other $(p<0.001)$.

A negative correlation was found between MPV and femoral neck T-score $(p=0.011, r=0.314)$. However, no significant correlation was found between MPV and lumbar 1-4 T-score (Table 2). 
Table 1. Laboratory and demographic features of patients with rheumatoid arthritis

\begin{tabular}{|c|c|c|c|c|}
\hline & Normal $(n=32)$ & Osteopenic $(n=31)$ & Osteoporotic $(n=45)$ & p-value \\
\hline Age (years) & $49.00(43.75-52.75)$ & $52.00(49.00-54.00)$ & $51.00(49.00-54.50)$ & 0.051 \\
\hline Height $(\mathrm{cm})$ & $1.60(1.57-1.67)$ & $1.56(1.52-1.61)$ & $1.54 *(1.47-1.60)$ & $<0.001$ \\
\hline Weight (kg) & $78.50(65.25-93.25)$ & $77.00(66.00-85.00)$ & $63.00 * *(52.50-77.00)$ & $<0.001$ \\
\hline $\mathrm{BMI}\left(\mathrm{kg} / \mathrm{m}^{2}\right)$ & $29.9(25.37-34.17)$ & $31.20(26.80-34.50)$ & $26.70 *(22.60-32.85)$ & 0.024 \\
\hline MPV (fL) & $10.55(9.72-11.75)$ & $10.70(9.90-11.50)$ & $11.00(9.60-11.15)$ & 0.600 \\
\hline Calcium (mg/dL) & $9.25(9.00-9.67)$ & $9.30(9.00-9.60)$ & $9.40(8.90-9.70)$ & 0.964 \\
\hline 25(OH)D3 (ng/mL) & $26.95(21.62-32.87)$ & $24.00(19.90-28.90)$ & $24.70(18.10-34.10)$ & 0.422 \\
\hline Lumbar 1-4 T-score & $-0.55(-1.12$ to 0.55$)$ & $-1.70(-1.90$ to 1.30$)$ & $-3.10(-3.70 \text { to }-2.50)^{* * *}$ & $<0.001$ \\
\hline Femoral neck T-score & $-0.40(-0.77$ to 0.12$)$ & $-0.90(-1.40$ to -0.20$)$ & $-2.50(-2.80$ to -1.60$)$ & $<0.001$ \\
\hline
\end{tabular}

*The osteoporotic and normal groups are different from each other, **The osteoporotic group is different from the other groups. ***All groups are different from each other, BMI: Body mass index, MPV: mean platelet volume

Table 2. The correlation analysis between mean platelet volume and bone mineral density

\begin{tabular}{|l|l|l|}
\hline & L1-L4 T-score & Femoral neck T-score \\
\hline MPV (fL) & & \\
\hline$p$ & 0.090 & -0.314 \\
\hline$r$ & 0.421 & 0.011 \\
\hline MPV: Mean platelet volume & & \\
\hline
\end{tabular}

\section{Discussion}

OP occurs frequently in patients with endocrine, hepatic, nutritional, hematological, renal, autoimmune, and rheumatic diseases such as RA, systemic lupus erythematosus (SLE), and ankylosing spondylitis (AS) (18). Local and systemic bone loss has been defined as hallmarks of RA (7). Meta-analyses showed higher fracture risk in RA patients compared with healthy controls (19). The low bone mass leads to fragility fractures. "Severe" or "established" OP was defined in the presence of one or more documented fragility fractures (6). In our study, we found 45 (41.6\%) patients with OP. The median lumbar and femoral T-scores for osteoporotic patients were -3.1 and -2.5 , respectively. There was no suspected compression fracture according to the medical history related to compression fractures such as sudden or gradual pain radiating to the lower parts of the body in patients included in our study. Moreover, compression fracture was not detected in the lumbar and dorsal direct radiographs of patients with suspicious symptoms.

In rheumatic diseases such as RA, proinflammatory cytokines such as IL-1, IL-6, and TNF- $\alpha$ play a critical role in osteoclast formation. These cytokines promote osteoclast differentiation, also termed as osteoclastogenesis (7). Therefore, inflammation was reported to decrease in BMD (7). The involvement of blood platelets and MPV in an inflammatory response is associated with the release of cytokines (20). The median MPV values were 10.55, 10.7, and $11.00 \mathrm{fL}$ for the normal, osteopenic, and osteoporotic groups, respectively. Resorlu et al. (12) assessed the relationship between BMD and MPV in AS patients. The study found that MPV values were higher in the osteopenic group than in the normal group $(8.4 \pm 0.81$ vs $9.08 \pm 1.05)$. In our study, the median MPV value was higher in osteoporotic patients than in normal and osteopenic patients. There was no statistically significant difference between the three groups in terms of MPV values. A significant correlation was found between MPV and femoral neck T-score in Resorlu et al.'s (12) study. They reported that systemic effects underlie elevated MPV values in osteopenic patients. Also, Li et al. (10) found a significantly negative correlation between MPV and femoral neck-lumbar spine BMD. In this study, significant differences were found for the median femur and lumbar T-score between the control, osteopenic, and osteoporotic groups. In our study, the median femoral neck T-scores were -0.4, -0.9, and -2.5 , and the lumbar T-scores were $-0.55,-1.7$, and -3.1 for the normal, osteopenic, and osteoporotic groups, respectively $(p<0.001$ for both). In contrast, a significantly positive correlation was reported between MPV and femoral neck BMD in the normal weight osteoporotic group (13). In addition, a significant negative correlation was found in the overweight-obese osteoporotic group in the same study (13). In our study, we found higher MPV levels in osteoporotic RA patients than in osteopenic RA patients. However, we did not find higher MPV levels in patients with normal BMD when we compared them with osteopenic RA patients. Also, we found a significant negative correlation between MPV and femoral neck T-scores. Although aging affects MPV, it has been stated previously that MPV may be affected by different cytokines and factors (9). Our results can also be explained with the differences in the storage time of the blood or with the use of different devices and kits for MPV measurement $(21,22)$.

Patients with higher BMI values have a lower OP prevalence $(23,24)$. Higher body weight imposes a greater mechanical load on the bone, which results in an increase in bone mass (25). Body fat seems to be a protective factor for fractures. Adipocytes induce estrogen production, which increases leptin, insulin, preptin, and amylin. These hormones have roles in osteoblast and osteoclast activities, and they increase the bone mass (26). In Li et al.'s (10) study, the median BMIs were 24.2, 23.4, and 21.6 for the control, osteopenic, and osteoporotic groups, respectively. In this study, there were significant differences between 
groups and significant association with lumbar spine L2-L4 BMD (10). In our study, the median BMI was 29.95 for the normal group, 31.2 for the osteopenic group, and 26.7 for the osteoporotic group. BMI was lower in the osteoporotic group than the other groups. Also, we found a significant correlation between the groups in terms of BMI $(p=0.02)$. However, no correlation was found between BMI and femur/lumbar T-scores.

\section{Study Limitations}

The limitation of the study is that this was a retrospective and crosssectional study without any control group. Also, we have no data on the parathormone level, inflammation markers, and disease activity.

\section{Conclusion}

To the best of our knowledge, our study is the first to assess the association between MPV and BMD in RA. In conclusion, this study has demonstrated that MPV levels are higher in osteoporotic RA patients and are correlated with femur neck BMD.

Ethics Committee Approval: Our study was conducted according to the criteria set by the Declaration of Helsinki, and the Aydın Adnan Menderes Faculty of Medicine Ethics Committee approved the study (approval no: 2017/1123, date: 23.03.2017).

Informed Consent: Written informed consent was obtained from all patients.

Peer-review: Externally peer-reviewed.

Financial Disclosure: The author declared that this study received no financial support.

\section{References}

1. Bullock J, Rizvi SAA, Saleh AM, Ahmed SS, Do DP, Ansari RA, et al. Rheumatoid arthritis: A brief overview of the treatment. Med Princ Pract 2018; 27: 501-7.

2. Smolen JS, Landewé RBM, Bijlsma JWJ, Burmester GR, Dougados M, Kerschbaumer A, et al. EULAR recommendations for the management of rheumatoid arthritis with synthetic and biological disease-modifying antirheumatic drugs: 2019 update. Ann Rheum Dis 2020; 79: 685-99.

3. Hauser B, Riches PL, Wilson JF, Horne AE, Ralston SH. Prevalence and clinical prediction of osteoporosis in a contemporary cohort of patients with rheumatoid arthritis. Rheumatology 2014; 53: 1759-66.

4. Lane NE. Epidemiology, etiology, and diagnosis of osteoporosis. Am J Obstet Gynecol 2006; 194(2 Suppl): 3-11.

5. Sözen T, Özışık L, Başaran NÇ. An overview and management of osteoporosis. Eur J Rheumatol 2017; 4: 46-56.

6. Kanis JA, Melton LJ, Christiansen C, Johnston CC, Khaltaev N. The diagnosis of osteoporosis. J Bone Miner Res 1994; 9: 1137-41.

7. Matuszewska A, Szechiński J. [Mechanisms of osteoporosis development in patients with rheumatoid arthritis]. Postepy Hig Med Dosw 2014; 68: 145-52.

8. Mori T, Miyamoto T, Yoshida H, Asakawa M, Kawasumi M, Kobayashi T, et al. IL-1 $\beta$ and TNF $\alpha$-initiated IL-6-STAT3 pathway is critical in mediating inflammatory cytokines and RANKL expression in inflammatory arthritis. Int Immunol 2011; 23: 701-12.
9. Gasparyan AY, Ayvazyan L, Mikhailidis DP, Kitas GD. Mean platelet volume: a link between thrombosis and inflammation? Curr Pharm Des 2011; 17: 47-58.

10. Li XS, Zhang JR, Meng SY, Li Y, Wang RT. Mean platelet volume is negatively associated with bone mineral density in postmenopausal women. J Bone Miner Metab 2012; 30: 660-5.

11. Akbal A, Gökmen F, Gencer M, Inceer BS, Kömürcü E. Mean platelet volume and platelet distribution width can be related to bone mineralization. Osteoporos Int 2014; 25: 2291-5.

12. Resorlu H, Resorlu M, Gokmen F, Akbal A, Adam G, Komurcu E, et al. Association between mean platelet volume and bone mineral density in patients with ankylosing spondylitis and diagnostic value of diffusionweighted magnetic resonance imaging. J Phys Ther Sci 2015;27:1137-40.

13. Aypak C, Türedi Ö, Bircan MA, Civelek GM, Araz M. Association between mean platelet volume and bone mineral density in postmenopausal women. J Phys Ther Sci 2016; 28: 1753-8.

14. Mohamad SF, Xu L, Ghosh J, Childress PJ, Abeysekera I, Himes ER, et al. Osteomacs interact with megakaryocytes and osteoblasts to regulate murine hematopoietic stem cell function. Blood Adv 2017; 1: 2520-8.

15. Kim J, Kim HS, Lee HS, Kwon YJ. The relationship between platelet count and bone mineral density: results from two independent population-based studies. Arch Osteoporos 2020; 15: 43.

16. D’Amelio P, Cristofaro MA, De Vivo E, Ravazzoli M, Grosso E, Di Bella S, et al Platelet vitamin $D$ receptor is reduced in osteoporotic patients. Panminerva Med 2012; 54: 225-31.

17. Aletaha D, Neogi T, Silman AJ, Funovits J, Felson DT, Bingham CO 3rd, et al. 2010 Rheumatoid arthritis classification criteria: an American College of Rheumatology/European League Against Rheumatism collaborative initiative. Arthritis Rheum 2010; 62: 2569-81.

18. Mirza F, Canalis E. Management of endocrine disease: Secondary osteoporosis: Pathophysiology and management. Eur J Endocrinol 2015; 173: R131-51.

19. Jin S, Hsieh E, Peng L, Yu C, Wang Y, Wu C, et al. Incidence of fractures among patients with rheumatoid arthritis: a systematic review and meta-analysis. Osteoporos Int 2018; 29: 1263-75.

20. Korniluk A, Koper-Lenkiewicz OM, Kamińska J, Kemona H, Dymicka-Piekarska VJ. Mean platelet volume (MPV): New perspectives for an old marker in the course and prognosis of inflammatory conditions. Mediators Inflamm. 2019; 2019: 9213074

21. Yazici S, Yazici M, Erer B, Erer B, Calik Y, Ozhan H, Ataoglu S. The platelet indices in patients with rheumatoid arthritis: mean platelet volume reflects disease activity. Platelets 2010; 21: 122-5.

22. Mazocco L, Chagas P. Association between body mass index and osteoporosis in women from northwestern Rio Grande do Sul. Rev Bras Reumatol Engl Ed 2017; 57: 299-305.

23. Głogowska-Szelagg J. [Assessment of the relationship between bmd and body mass index bmi in women with postmenopausal osteoporosis]. Wiad Lek 2018; 71: 1714-8.

24. Zhao LJ, Liu YJ, Liu PY, Hamilton J, Recker RR, Deng HW. Relationship of obesity with osteoporosis. J Clin Endocrinol Metab 2007; 92: 1640-6.

25. Martini LA, de Moura EC, dos Santos LC, Malta DC, de de Medeiros Pinheiro M. Prevalência de diagnóstico autorreferido de osteoporose, Brasil, 2006. Rev Saúde Pública 2009; 43: 107-16.

26. Reid IR. Relationships among body mass, its components, and bone. Bone 2002; 31: 547-55 